\title{
THE NEW INJURIES' RISK AFTER ACL RECONSTRUCTION MIGHT BE REDUCED WITH FUNCTIONAL TRAINING
}

\section{O RISCO DE NOVAS LESÕES APÓS RECONSTRUÇÃO DO LCA PODE SER MINORADO COM O TREINAMENTO FUNCIONAL}

\author{
Julio Cesar Gali ${ }^{1}$ (D), Guilia Wendt Fadel ${ }^{1}$ (D), Marcos Felipe Marques ${ }^{2}$ (D), Tyago araújo almeida ${ }^{2}$ (D), \\ Julio Cesar Gali Filho 3 (1), Felipe AleXandre Separovic Faria ${ }^{3}$ (i)
} 1. Pontifícia Universidade Católica de São Paulo, School of Medical Sciences and Health of Sorocaba, Department of Surgery, Sorocaba, SP, Brazil.
2. Fundação São Paulo, Hospital Santa Lucinda, Orthopedic Service, Sorocaba, SP, Brazil.

3. Núcleo de Ortopedia e Traumatologia do Esporte, Sorocaba, SP, Brazil.

\section{ABSTRACT}

Objective: The objective of our study was to evaluate if functional training with the Functional Movement Screen (FMS) can reduce the risk of a new injury for patients that underwent an anterior cruciate ligament reconstruction (ACLR). Our hypothesis was that the functional training might reduce the risk of a new injury. Methods: Our training protocol consisted of six phases, each one lasting six weeks. It began two months after surgery. The study group was composed of 10 individuals that completed our protocol after ACLR. The control group consisted of 10 people that completed a regular ACLR rehabilitation protocol. The FMS was used to compare the study and control group performance. Patients with a score of 14 or less on the FMS were considered more likely to suffer an injury than those with a score higher than 14. Results: The study group average FMS score was 16.6 compared to the control group at 12.3. Functional training for ACLR rehabilitation added a statistically significant benefit $(p<0.0002)$ to reduce the risk of a new injury compared to regular protocol. Conclusion: Functional training may be considered an alternative to the regular ACLR rehabilitation to reduce the risk of a new injury before returning to sports. Level of Evidence III, Case control study.

Keywords: Knee Injuries. Ligaments. Rehabilitation.

\section{RESUMO}

Objetivo: Nosso objetivo foi avaliar se o treinamento funcional pode reduzir o risco de nova lesão, após a reconstrução do ligamento cruzado anterior (RLCA), pelo Functional Movement Screen (FMS). Nossa hipótese foi que o treinamento funcional pode diminuir o risco de nova lesão. Métodos: O treinamento consistiu de seis fases de seis semanas cada uma. Começou dois meses após a reconstrução do ligamento. O grupo estudo foi composto por 10 indivíduos que completaram o treinamento, após a RLCA. O grupo controle consistiu em 10 pessoas que fizeram o protocolo regular de reabilitação da RLCA. O FMS foi utilizado para comparar o desempenho dos dois grupos. Pacientes com pontuação igual ou inferior a 14 foram considerados mais propensos a sofrer nova lesão em comparação àqueles com pontuação maior que 14. Resultados: A pontuação média do grupo estudo foi de 16,6 e a do grupo controle, 12,3. O treinamento funcional adicionou um benefício estatisticamente significativo ( $p<0,0002)$ para diminuir o risco de nova lesão, em comparação com o protocolo regular. Conclusão: O treinamento funcional pode ser mais uma estratégia a ser incluida na reabilitação regular da $R L C A$, para diminuir o risco de uma nova lesão, antes de retornar ao esporte. Nível de Evidência III, Estudo de Caso controle.

Descritores: Traumatismos do Joelho. Ligamentos. Reabilitação.

Citation: Gali JC, Fadel GW, Marques MF, Almeida TA, Gali Filho JC, Faria FAS. The new injuries' risk after ACL reconstruction might be reduced with functional training. Acta Ortop Bras. [online]. 2021;29(1):21-5. Available from URL: http://www.scielo.br/aob.

\section{INTRODUCTION}

In the United States of America, approximately $90 \%$ of patients undergoing anterior cruciate ligament (ACL) injury had their ligament reconstructed. ${ }^{1}$ After surgery, specific rehabilitation programs are used to restore joint movement, improve muscle strength and conditioning, and provide a safe return to sports participation. However, the standard anterior cruciate ligament reconstruction (ACLR) rehabilitation is not a guarantee for a return to sports at

All authors declare no potential conflict of interest related to this article.

The study was conducted Faculdade de Ciências Médicas e da Saúde da Pontifícia Universidade Católica de São Paulo - Sorocaba Correspondence: Julio Cesar Gali. Rua Caracas 418, Sorocaba, SP, Brazil, 18046718. jcgali@pucsp.br 
the previous activity level and for continued participation in the desired sport. $^{2}$

After an ACL injury, proprioception and neuromuscular control of the knee are impaired, which may persist subsequently to reconstruction and surgical rehabilitation. ${ }^{3}$ On the other hand, inadequate neuromuscular control may be a risk both for the first ACL injury ${ }^{4,5}$ and for recurrent instabilities. ${ }^{6}$

The neuromuscular training program has been used to prevent $\mathrm{ACL}$ injuries in female athletes ${ }^{7-9}$ and to avoid injuries in adolescents and adults. ${ }^{10}$ Risberg and Holm ${ }^{11}$ suggested that neuromuscular training should be part of the rehabilitation program after ACLR. Wiggins et al., in a systematic review and meta-analysis, proposed that neuromuscular training can help athletes under 25 to return more safely to the sport and reduce the risk of a second injury. ${ }^{12}$ Huang et al., ${ }^{13}$ in a systematic review of randomized clinical trials, reported that an ACL injury prevention program had a significant positive effect and reduced the injury rate by $53 \%$.

Closed kinetic chain evaluation has been used to test patients' strength and ability to advance to a more complex functional level. ${ }^{14}$ Functional tests, such as single leg and vertical jumping, are generally used to determine knee function after ligament reconstruction. ${ }^{15,16}$ However, an objective and accepted method of evaluation is needed to determine how an athlete will develop in the final phase of rehabilitation and if he will have a safe return to sports. ${ }^{17}$ Recently, a score $\leq 14$ measured by the Functional Movement Screen (FMS) was considered a detectable risk factor for injuries in professional soccer players. ${ }^{18}$ Using the FMS score, Boyle et al. ${ }^{19}$ found that adolescents were at increased risk for lower limb injuries after 9 months of ACLR.

However, there is no concrete way to evaluate neuromuscular control in individuals whose ACL was reconstructed. The objective of our study was to evaluate if our functional training algorithm can decrease the risk assessment of a new lesion in patients that underwent ACLR, using the FMS scoring system.

\section{MATERIALS AND METHODS}

Informed consent was obtained from all patients participating in the study and the study was approved by our institution's Ethics Committee under the number CAAE: 32800116.0.0000.5373. Inclusion criteria were considered patients that had unilateral primary anatomic ACLR with ischiotibial tendon graft for the treatment of chronic lesions and, to the exclusion, patients with acute lesions, reconstructions with other type of graft than the ischiotibial ones, revision or reconstruction of another ligament associated to ACLR and patients with bilateral lesions. No patient was a professional athlete, but all performed at least 50 hours of sports activities per year.

Immediate total body weight support, with crutches, and full range of motion was allowed for all patients from the first postoperative day. No immobilization was used. The crutches were removed after seven days, as long as there was no claudication.

After that, the patients were divided into two groups, study and control. The study group consisted of 10 individuals that completed the proposed functional training protocol after two months of physiotherapy rehabilitation. In this group, there were eight men and two women, aged between 25 and 53 years, with an average of 37.5 years. Regarding the side, six right knees were and four left knees were treated. The protocol consisted of a 36-week training period, starting right after the rehabilitation period. This practice was divided in six phases of six weeks each, and the exercises were performed three times a week. It was based on exercises of central stability (paravertebral, abdominal and hip musculature), correction of asymmetries in the lower limbs and neuromuscular deficits to improve neuromuscular control and minimize the risk of future injuries (Table 1).

Table 1. Functional Training Protocol.

\begin{tabular}{|c|c|c|}
\hline Phase I: Week 1 to 6 & Phase II: Week 7 to 12 & Phase III: Week 13 to 18 \\
\hline $\begin{array}{l}\text { Goals: } \\
>\text { To restore fundamental movement patterns } \\
>\text { To establish the domain of the hip and knee } \\
>\text { To adequate movement patterns for physical activities }\end{array}$ & $\begin{array}{l}\text { Goals: } \\
\text { To emphasize unilateral exercises } \\
>\text { To minimize limb asymmetries and } \\
\text { general deficits (strength, joint stability / } \\
\text { mobility and neuromuscular control) }\end{array}$ & $\begin{array}{l}\text { Goals: } \\
\text { To provide greater range of motion, control } \\
\text { and perception in various positions }\end{array}$ \\
\hline $\begin{array}{l}\text { - Bridge: } 20 \mathrm{sec} \text { / } 8 \text { repetitions } \\
\text { - Board: } 30 \mathrm{sec} \\
\text { - Educational squat: Medium mini-band / } \\
3 \mathrm{~kg} \text { medicine ball / } 10 \text { repetitions } \\
\text { - Activation of the plantar arch + lateral } \\
\text { displacement: Medium mini-band / } 4 \mathrm{~m} \\
\text { - Educational charge: Stick / } 8 \text { repetitions } \\
\text { - Root leg activation: } 10 \text { repetitions } \\
\text { - Adduction with band: Light band / } 10 \text { repetitions } \\
\text { - Educational land survey: Baton / } 10 \text { repetitions } \\
\text { - Lunge: } 3 \text { kg medical ball / } 8 \text { reps } \\
\text { - Ankle mobility with knee flexion: } 10 \text { repetitions }\end{array}$ & $\begin{array}{l}\text { - TRX bridge: } 20 \mathrm{sec} \text { / } 6 \text { repetitions } \\
\text { - Board: } 30 \mathrm{sec} \\
\text { - One-sidwed squat: } 2 \mathrm{~kg} \text { medicine ball / } 6 \text { repetitions } \\
\text { - Unilateral rotational hip mobility with stick: } 4 \text { repetitions } \\
\text { - Unilateral educational land survey: Baton / } 6 \text { repetitions } \\
\text { - Side displacement: super band / } 4 \mathrm{~m} \\
\text { - Activation of the root leg with light band / } 10 \text { repetitions } \\
\text { - Bulgarian squat: } 3 \mathrm{~kg} \text { medicine ball / } 8 \text { reps } \\
\text { - String: } 30 \mathrm{sec} \\
\text { - Unilateral plyometrics: } 20 \mathrm{~cm} \text { box / } 6 \text { repetitions } \\
\text { - Pullover with ball: } 6 \text { repetitions }\end{array}$ & $\begin{array}{l}\text { - Bridge on the ball: } 20 \mathrm{sec} \text { / } 6 \text { repetitions } \\
\text { - Board on the ball: } 30 \mathrm{sec} \\
\text { - Climb in box: stick / } 8 \text { repetitions } \\
\text { - Stick and box for hip mobility, } \\
\text { semi-kneeling: } 20 \mathrm{sec} \text { / } 5 \text { repetitions } \\
\text { - Deadlift: } 10 \mathrm{~kg} \text { / } 10 \text { repetitions } \\
\text { - TRX unilateral hip rotational mobility: } 6 \text { repetitions } \\
\text { - Front displacement with medium mini-band: } 4 \text { meters } \\
\text { - Unilateral Lifting with Kettlebell: } 4 \mathrm{~kg} \text { / } 6 \text { repetitions } \\
\text { - Semi-knees anti-rotation with band: } 6 \text { repetitions } \\
\text { - Side board: } 20 \text { sec } \\
\text { - Slide: } 1 \text { min } \\
\text { - Lateral attack with external rotation: stick / } 6 \text { repetitions } \\
\text { - Plyometric circuit with medium mini-band: } 8 \text { repetitions } \\
\text { - One in / low knee agility: } 3 \text { strides } \\
\text { - One in / low knee agility: } 3 \text { strides } \\
\text { - Treadmill run: } 20 \text { min / Lightweight: } 50 \text { - } \\
60 \% \text { of maximum heart rate }\end{array}$ \\
\hline
\end{tabular}


Table 1. Functional Training Protocol.

\begin{tabular}{|c|c|c|}
\hline Phase IV: Week 19 to 24 & Phase V: Week 25 to 30 & Phase VI: Week 31 to 36 \\
\hline $\begin{array}{l}\text { Goals: } \\
\text { To provide the ability to generate power } \\
\text { through a highly coordinated and efficient } \\
\text { movement between body segments }\end{array}$ & $\begin{array}{l}\text { Goals: } \\
>\text { To maintain the ability to generate power } \\
\text { through highly coordinated movements } \\
>\text { To provide conditions for training } \\
\text { and developing specific skills }\end{array}$ & $\begin{array}{l}\text { Goals: } \\
>\text { To maintain the physical capabilities } \\
\text { already acquired } \\
>\text { To provide optimal conditions for training and } \\
\text { developing specific skills without wasting energy }\end{array}$ \\
\hline $\begin{array}{l}\text { - Slide bridge: } 20 \mathrm{sec} \text { / } 6 \text { repetitions } \\
\text { - Slide board: } 30 \mathrm{sec} / 6 \text { repetitions } \\
\text { - Plyometric Squat: } 5 \mathrm{~kg} / 10 \text { repetitions } \\
\text { - Balance board: } 45 \mathrm{sec} \\
\text { - Unilateral hip activation in the box: } 20 \mathrm{sec} \\
\text { - Strong miniband lateral displacement / 4m } \\
\text { - Swing Kettlebell: } 10 \mathrm{~kg} / 10 \text { repetitions } \\
\text { - Hip flexion and alternate knee on TRX: } 10 \text { repetitions } \\
\text { - Low sequential plyometrics: } 5 \text { repetitions / } 30-35-40 \mathrm{~cm} \\
\text { - Agility One in / high knee: } 3 \text { passes } \\
\text { - Agility Two in / high knee: } 3 \text { passes } \\
\text { - Agility Half Carioca: } 3 \text { tickets } \\
\text { - Treadmill Run: } 30 \text { min / Light } 50-60 \% \text { HR Max }\end{array}$ & $\begin{array}{l}\text { - TRX bridge: } 20 \mathrm{sec} \text { / } 6 \text { repetitions } \\
\text { - TRX unilateral board: } 20 \mathrm{sec} \\
\text { - TRX unilateral onslaught: } 10 \text { reps } \\
\text { - Mobility rotational hip stick unstable: } 5 \text { repetitions } \\
\text { - Sled: } 6 \times 10 \text { meters / } 50 \mathrm{~kg} \\
\text { - Side board with TRX rotation: } 20 \mathrm{sec} \text { / } 4 \text { repetitions } \\
\text { - Pullover Roller: } 6 \text { reps } \\
\text { - Olympic Weightlifting: } 6 \text { reps } 5 \mathrm{~kg} \text { / } 3 \text { reps } 10 \mathrm{~kg} \\
\text { - Side shift + SuperBand squat: } 4 \mathrm{~m} \text { / Medium SuperBand } \\
\text { - SuperBand lateral plyometrics: } 8 \times \\
\text { each side / Average SuperBand } \\
\text { - Agility Half Carioca: } 3 \text { tickets } \\
\text { - Agility Slalon Jump: } 3 \text { passes } \\
\text { - Agility Two in Lateral: } 3 \text { passes } \\
\text { - Cross agility two in: } 3 \text { tickets } \\
\text { - Cross agility feint: } 3 \text { passes } \\
\text { - Educational / Running Hopserlauf: } 2 \times 20 \mathrm{~m} \\
\text { - Educational / Running Hopserlauf Kick: } 2 \times 20 \mathrm{~m} \\
\text { - Educational / Side Race Run: } 2 \times x 20 \mathrm{~m}\end{array}$ & $\begin{array}{l}\text { - TRX unilateral onslaught: } 10 \text { reps } \\
\text { - SuperBand crouching lateral displacement: } \\
\text { 4m / Medium Superband } \\
\text { - Forward and reverse displacement: } 6 \mathrm{~kg} / 6 \text { repetitions } \\
\text { - Slide adduction: } 8 \text { repetitions / } 3 \mathrm{~kg} \text { medicine ball } \\
\text { - TRX Hip Flexed Side Plank: } 6 \text { reps } \\
\text { - Olympic Weightlifting: } 10 \text { reps / } 5 \mathrm{~kg} \\
\text { - TRX low pullover: } 6 \text { repetitions } \\
\text { - Sequential Plyometry in Total Flexion: } 10 \times \text { / } 40 \mathrm{~cm} \\
\text { - Educational / Running } \\
\text { - Side run with change of direction: } 3 \times 30 \mathrm{~m} \\
\text { - Front / back running: } 3 \times 30 \mathrm{~m} \\
\text { - } 360 \times \text { swing race: } 3 \times 30 \mathrm{~m} \\
\text { - Diagonal run with spin: } 3 \times 10 \mathrm{~m} \\
\text { - Running field: } 30 \mathrm{~min} / \text { Moderate } 60-75 \% \text { FC Max }\end{array}$ \\
\hline
\end{tabular}

The control group also consisted of 10 people, nine men and one woman, who underwent two months of physical therapy and a regular $A C R L$ rehabilitation protocol, including muscle strengthening, resistance, proprioception, plyometrics and specific training, for six months. ${ }^{20}$ The patients were aged between 19 and 46 years, with a mean of 32.1 years. There were five right and five left knees in this group.

Both groups had comparable range of motion, joint stability and trophism of the thigh muscles. FMS was used to compare the performance of the two groups. The study group was assessed immediately after 36 weeks of functional training and the control group was assessed immediately after standard ACRL rehabilitation. The FMS analyzes the quality of seven fundamental movement patterns, applied to verify mobility, stability, neuromuscular and motor control to diagnose limitations and / or asymmetries (Figure 1).

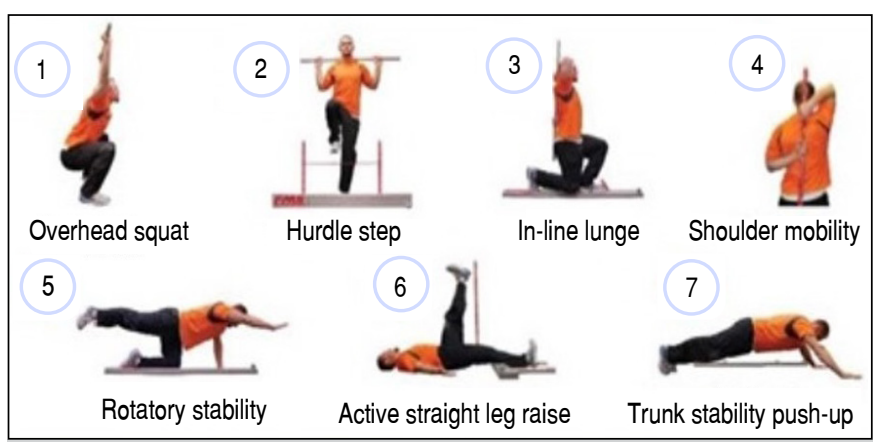

Figura 1. Seven tests from Functional Movement Screen. Source: https://lifestyle.fit/entrenamiento/rutinas/fms-test-movilidad-funcional-movement-screen.

Patients with a score of 14 or less on the FMS were considered more likely to suffer a new injury than those with a higher score. ${ }^{21,22}$
All tests were performed by an experienced and judicious physical educator.

\section{Statistical analysis}

The Mann-Whitney test and Fisher's exact test were used to compare the FMS score, age, gender and affected side of the two groups. The level of significance (a) established was 0.05 or $5 \%$.

\section{RESULTS}

There was no statistically significant correlation between age, gender, side involved and FMS score. The average FMS score for the study group was 16.6, for the control group, 12.3. Tables 2 and 3 listed demographic data and FMS scores.

Table 2. Age, Gender, Side and FMS Score of Study Group Patients.

\begin{tabular}{c|c|c|c|c}
\hline Patient & Age & Gender & Side & Score \\
\hline 1 & 27 & $\mathrm{M}$ & $\mathrm{R}$ & 18 \\
\hline 2 & 43 & $\mathrm{M}$ & $\mathrm{R}$ & 14 \\
\hline 3 & 37 & $\mathrm{M}$ & $\mathrm{L}$ & 16 \\
\hline 4 & 32 & $\mathrm{~F}$ & $\mathrm{R}$ & 19 \\
\hline 5 & 53 & $\mathrm{M}$ & $\mathrm{R}$ & 16 \\
\hline 6 & 34 & $\mathrm{M}$ & $\mathrm{L}$ & 16 \\
\hline 7 & 25 & $\mathrm{~F}$ & $\mathrm{R}$ & 18 \\
\hline 8 & 42 & $\mathrm{M}$ & $\mathrm{R}$ & 16 \\
\hline 9 & 45 & $\mathrm{M}$ & $\mathrm{L}$ & 15 \\
\hline 10 & 37 & $\mathrm{~F}$ & $\mathrm{~L}$ & 18 \\
\hline & 37.5 & & & 16.6 \\
\hline
\end{tabular}




\begin{tabular}{c|c|c|c|c}
\multicolumn{5}{c}{ Table 3. Age, Gender, Side and FMS Score of Control Group Patients. } \\
\hline Patient & Age & Gender & Side & Score \\
\hline 1 & 38 & M & L & 13 \\
\hline 2 & 31 & M & R & 12 \\
\hline 3 & 19 & M & R & 14 \\
\hline 4 & 26 & M & R & 13 \\
\hline 5 & 45 & M & L & 12 \\
\hline 6 & 34 & M & L & 12 \\
\hline 7 & 46 & F & R & 11 \\
\hline 8 & 19 & M & L & 12 \\
\hline 9 & 23 & M & L & 13 \\
\hline 10 & 40 & M & R & 11 \\
\hline & 32.1 & & & 12.3 \\
\hline
\end{tabular}

According to the FMS score, functional training for rehabilitation of knee with ACLR added a statistically significant benefit $(p<0.0002)$ to decrease the risk of further injury compared to the regular rehabilitation protocol.

\section{DISCUSSION}

The results of our study suggest that functional training can be recommended for ACLR rehabilitation programs. Literally, functional means described from the required design; so we can say that this exercise was specially planned for the rehabilitation of ACLR. Functional training combines neuromuscular control, joint mobility and stability, central stability, trunk alignment and lower limb joints. Ageberg and Roos ${ }^{23}$ defined neuromuscular control (sensorimotor control) as the ability to produce controlled movement by coordinated muscle activity.

Central stability seeks to strengthen abdominal, paravertebral and gluteal muscles to produce maximum stability in the abdomen and spine. It can be defined as the ability of the lumbopelvic-hip complex to prevent buckling of the spine and return it to balance after disturbance ${ }^{24}$ It provides a stable base for the movement of the extremities and its training uses the central muscles in daily tasks and sports-related activities. ${ }^{25}$ Moreover, muscle fatigue alters neuromuscular control, decreases the strength of the central musculature and the capacity of proprioception, which may increase the risk of $\mathrm{ACL}$ non-contact injuries. ${ }^{26}$

Unlike traditional muscle strengthening programs, several joints and muscles are exercised in the three planes of movement during functional training, simultaneously challenging the brain and the body. In fact, intervention programs that target multiple load plans are needed to effectively reduce the risk of ACL injury. ${ }^{27}$

In our protocol, the agonist and antagonist muscles are co-activated to maintain the balance of the segments under tension, in static and dynamic situations. Functional training can also provide muscle strength, power and endurance. In this type of practice, the efficiency and quality of the movements are mandatory. The compensatory patterns of patients can also be assessed, and continuous supervision can provide possible adjustments to improve function. Whereas regular muscle strength programs usually work on the sagittal or coronal planes, functional training also works on the transversal plane, where ACL injuries usually occur.

We believe this is the first study that evaluated the response of functional training in individuals with ACLR using the FMS Scoring System. One of the objectives of our protocol was to prevent ACL injury mechanisms (adduction and internal rotation of the hip, knee valgus, external rotation and anterior translation of the tibia and eversion of the ankle). ${ }^{28,29}$ More recently, Kiapour

et al., using a cadaveric landing model, proposed that knee valgus collapse is one of the main mechanisms of contactless ACL injuries in falls. ${ }^{27}$

With training exercises, the proposed protocol sought to work the balance between external and internal hip rotators, knee flexors and extensors and ankle invertors and evertors, to obtain dynamic knee stabilization. Thus, the dominance of the quadriceps, which could cause an increase in the ACL tension level and make it more susceptible to injuries, ${ }^{30}$ was corrected by dynamic neuromuscular training. ${ }^{31}$

The FMS score was chosen to evaluate the study and control groups, because it analyzes the whole body working together. The test helps to identify deficits in mobility, stability and neuromuscular coordination. To successfully complete the seven fundamental patterns of movement, muscle strength, flexibility, range of motion, coordination, balance and proprioception are required. ${ }^{18}$

Kiesel et al. ${ }^{18}$ suggested that a low FMS score is a proven risk factor for injuries in professional soccer players, whereas Bushman et al. ${ }^{32}$ considered that, although the low performance of the FMS was associated with a higher risk of injuries, it showed low sensitivity and low positive predictive value for physically active male soldiers. More recently, Bonazza et al., ${ }^{33}$ based on the results of a systematic review and meta-analysis, reported that the FMS has excellent inter- and intra-examiner reliability. They concluded that people with a score $\leq 14$ on the FMS score are more than twice as likely to suffer a musculoskeletal injury as those with a score $\geq 14$.

Our study showed that functional training after ACRL decreased the likelihood of the risk of new injuries when compared with the regular rehabilitation protocol, according to the FMS scoring system. Therefore, the suggested functional training can be a new tool to support the promotion of a safe return to sports activities after ACRL. To reduce the risk of a new ACL injury, patients should continue training at least twice a week, and a longer follow-up is mandatory. Multicenter cohort studies are needed to endorse the efficiency of the proposed protocol in preventing new ACL injuries after rehabilitation.

Our study has some limitations. The main limitation is the small number of participants in each group and the fact that this number was not based on the estimation of the sample size. Since training is demanding and time-consuming, many patients did not have the persistence to complete it. In fact, Slauterbeck et al. ${ }^{34}$ reported that, according to the coaches, a compliance with an injury prevention program of at least twice a week is low. The second limitation is the small number of women, two in the intervention group and one in the control group, since the incidence of $\mathrm{ACL}$ injuries and the risk of new injury are higher in this gender. On the other hand, our objective was to assess the new risk of new injury for patients that had ACLR using the FMS scoring system. Furthermore, in the general population, the number of men that suffer ACL injuries is greater.

Another limitation was that the tests were performed by only one person, which can increase the chance of subjective influence. However, Bonazza et al. ${ }^{33}$ and Teyhen et al..$^{35}$ reported that the FMS scoring system showed moderate to good inter-rater reliability, with acceptable levels of measurement error. ${ }^{33}$ Finally, other tests were not performed, including the one-leg jump, the vertical jump and isokinetic testing.

\section{CONCLUSION}

Functional training can be included in regular ACLR rehabilitation before returning to sports, with the aim of decreasing the risk of a new injury. 
AUTHORS' CONTRIBUTIONS: Each author contributed individually and significantly to the development of this article. JCG: writing, performing surgeries and final approval of the version of the manuscript to be published; GWF: data collection and critical review of its intellectual content; MFM: data collection and performing surgeries; TAA: data collection and performing surgeries; JCGF: substantial contribution in the design of the work and final approval of the version of the manuscript to be published; FASF: analysis or interpretation of data and critical review of its intellectual content.

\section{REFERENCES}

1. Linko E, Harilainen A, Malmivaara A, Seitsalo S. Surgical versus conservative interventions for anterior cruciate ligament ruptures in adults. Cochrane Database Syst Rev. 2005;18(2):CD001356.

2. Hewett TE, Di Stasi SL, Myer GD. Current Concepts for Injury Prevention in Athletes After Anterior Cruciate Ligament Reconstruction. Am J Sports Med 2013;41(1):216-24

3. Hewett TE, Paterno MV, Myer GD. Strategies for enhancing proprioception and neuromuscular control of the knee. Clin Orthop Relat Res. 2002;(402):76-94.

4. Hewett TE, Myer GD, Ford KR, Heidt RS Jr, Colosimo AJ, McLean SG, et al. Biomechanical measures of neuromuscular control and valgus loading of the knee predict anterior cruciate ligament injury risk in female athletes: a prospective study. Am J Sports Med. 2005;33(4):492-501.

5. Myer GD, Martin L Jr, Ford KR, Paterno MV, Schmitt LC, Heidt RS Jr, et al. No association of time from surgery with functional deficits in athletes after anterior cruciate ligament reconstruction: evidence for objective return-to-sport criteria. Am J Sports Med. 2012;40(10):2256-63.

6. Paterno MV, Schmitt LC, Ford KR, Rauh MJ, Myer GD, Huang B, et al. Biomechanical measures during landing and postural stability predict second anterior cruciate ligament injury after anterior cruciate ligament reconstruction and return to sport. Am J Sports Med. 2010;38(10):1968-78.

7. Mandelbaum BR, Silvers HJ, Watanabe DS, Knarr JF, Thomas SD, Griffin LY, et al. Effectiveness of a neuromuscular and proprioceptive training program in preventing anterior cruciate ligament injuries in female athletes: 2-year follow-up. Am J Sports Med. 2005;33(7):1003-10.

8. Hewett TE, Ford KR, Myer GD. Anterior cruciate ligament injuries in female athletes: Part 2, a meta-analysis of neuromuscular interventions aimed at injury prevention. Am J Sports Med. 2006;34(3):490-8.

9. Wingfield K. Neuromuscular training to prevent knee injuries in adolescent female soccer players. Clin J Sport Med. 2013;23(5):407-8.

10. Gagnier JJ, Morgenstern H, Chess L. Interventions designed to prevent anterior cruciate ligament injuries in adolescents and adults: a systematic review and meta-analysis. Am J Sports Med. 2013;41(8):1952-62.

11. Risberg MA, Holm I. The long-term effect of 2 postoperative rehabilitation programs after anterior cruciate ligament reconstruction: a randomized controlled clinical trial with 2 years of follow-up. Am J Sports Med. 2009;37(10):1958-66.

12. Wiggins AJ, Grandhi RK, Schneider DK, Stanfield D, Webster KE, Myer GD. Risk of Secondary Injury in Younger Athletes After Anterior Cruciate Ligament Reconstruction: A Systematic Review and Meta-analysis. Am J Sports Med. 2016;44(7):1861-76.

13. Huang YL, Jung J, Mulligan CMS, Oh J, Norcross MF. A Majority of Anterior Cruciate Ligament Injuries Can Be Prevented by Injury Prevention Programs: A Systematic Review of Randomized Controlled Trials and Cluster-Randomized Controlled Trials With Meta-analysis. Am J Sports Med. 2020;48(6):1505-15.

14. Anderson MA, Gieck JH, Perrin DH, Weltman A, Rutt RA, Denegar CR. The Relationships among Isometric, Isotonic, and Isokinetic Concentric and Eccentric Quadriceps and Hamstring Force and Three Components of Athletic Performance. J Orthop Sports Phys Ther. 1991;14(3):114-20.

15. Reid A, Birmingham TB, Stratford PW, Alcock GK, Giffin JR. Hop testing provides a reliable and valid outcome measure during rehabilitation after anterior cruciate ligament reconstruction. Phys Ther. 2007;87(3):337-49.

16. Paterno MV, Ford KR, Myer GD, Heyl R, Hewett TE. Limb asymmetries in landing and jumping 2 years following anterior cruciate ligament reconstruction. Clin J Sport Med. 2007;17(4):258-62.
17. Myer GD, Paterno MV, Ford KR, Hewett TE. Neuromuscular training techniques to target deficits before return to sport after anterior cruciate ligament reconstruction. J Strength Cond Res. 2008;22(3):987-1014.

18. Kiesel K, Plisky PJ, Voight ML. Can Serious Injury in Professional Football be Predicted by a Preseason Functional Movement Screen? Am J Sports Phys Ther. 2007;2(3):147-58.

19. Boyle MJ, Butler RJ, Queen RM. Functional Movement Competency and Dynamic Balance After Anterior Cruciate Ligament Reconstruction in Adolescent Patients. J Pediatr Orthop. 2016;36(1):36-41.

20. Gali JC, Camanho GL. A reabilitação acelerada após reconstrução do ligamento cruzado anterior com enxerto de tendão patelar é segura? Rev Bras Ortop. 1998; 33(8): 645-50.

21. Cook G, Burton L, Hoogenboom BJ, Voight M. Functional movement screening: the use of fundamental movements as an assessment of function - part 1. Int J Sports Phys Ther. 2014; 9(3):396-409.

22. Cook G, Burton L, Hoogenboom BJ, Voight M. Functional movement screening: the use of fundamental movements as an assessment of function-part 2 Int J Sports Phys Ther. 2014; 9(4):549-63.

23. Ageberg E, Roos EM. Neuromuscular Exercise as Treatment of Degenerative Knee Disease. Exerc Sport Sci Rev. 2015;43(1):14-22.

24. Pope $\mathrm{MH}$, Panjabi M. Biomechanical definitions of spinal instability. Spine. 1985;10(3):255-6.

25. Willson JD, Dougherty CP, Ireland ML, Davis IM. Core stability and its relationship to lower extremity function and injury. J Am Acad Orthop Surg. 2005;13(5):316-25.

26. Alentorn-Geli E, Myer GD, Silvers HJ, Samitier G, Romero D, Lázaro-Haro C, et al. Prevention of non-contact anterior cruciate ligament injuries in soccer players. Part 1: Mechanisms of injury and underlying risk factors. Knee Surg Sports Traumatol Arthrosc. 2009;17(7):705-29.

27. Kiapour AM, Demetropoulos CK, Kiapour A, Quatman CE, Wordeman SC, et al. Strain Response of the Anterior Cruciate Ligament to Uniplanar and Multiplanar Loads During Simulated Landings: Implications for Injury Mechanism. Am J Sports Med. 2016;44(8):2087-96.

28. Olsen OE, Myklebust G, Engebretsen L, Bahr R. Injury mechanisms for anterior cruciate ligament injuries in team handball: a systematic video analysis. Am J Sports Med. 2004;32(4):1002-12.

29. Hewett TE, Myer GD, Ford KR. Anterior cruciate ligament injuries in female athletes: Part 1, mechanisms and risk factors. Am J Sports Med. 2006;34(2):299-311.

30. Renström P, Arms SW, Stanwyck TS, Johnson RJ, Pope MH. Strain within the anterior cruciate ligament during hamstring and quadriceps activity. Am J Sports Med. 1986;14(1):83-7.

31. Hewett TE, Johnson DL. ACL prevention programs: fact or fiction? Orthopedics. 2010;33(1):36-9.

32. Bushman TT, Grier TL, Canham-Chervak M, Anderson MK, North WJ, Jones BH. The Functional Movement Screen and Injury Risk: Association and Predictive Value in Active Men. Am J Sports Med. 2016;44(2):297-304.

33. Bonazza NA, Smuin D, Onks CA, Silvis ML, Dhawan A. Reliability, Validity, and Injury Predictive Value of the Functional Movement Screen. Am J Sports Med. 2017;45(3):725-32.

34. Slauterbeck JR, Choquette R, Tourville TW, Krug M, Mandelbaum BR, Vacek P, et al. Implementation of the FIFA 11+ Injury Prevention Program by High School Athletic Teams Did Not Reduce Lower Extremity Injuries: A Cluster Randomized Controlled Trial. Am J Sports Med. 2019;47(12):2844-52.

35. Teyhen DS, Shaffer SW, Lorenson CL, Halfpap JP, Donofry DF, Walker MJ, et al. The Functional Movement Screen: a reliability study. J Orthop Sports Phys Ther. 2012;42(6):530-40. 